\title{
PHYTOCHEMICAL TEST AND ANTIBACTERIAL BIOACTIVITY OF EXTRACTS FROM Artocarpus integer (Thunb.) Merr Stem Bark
}

\author{
Liska Hamzah $^{1}$, Nunuk Hariani Soekanto ${ }^{2,3 *}$, Firdaus $^{2,3}$ \\ ${ }^{1}$ Master Program of Chemistry, Faculty of Mathematics and Natural Science, Hasanuddin University, Perintis \\ Kemerdekaan Street KM. 10 Tamalanrea, Makassar, Indonesia 90245 \\ ${ }^{2}$ Department of Chemistry, Faculty of Mathematics and Natural Science, Hasanuddin University, Perintis \\ Kemerdekaan Street KM. 10 Tamalanrea, Makassar, Indonesia 90245 \\ *Corresponding author: nunukhariani@unhas.ac.id
}

\begin{abstract}
Abstrak. Penelitian ini bertujuan untuk mengidentifikasi golongan senyawa dan menguji aktivitas antibakteri dari fraksi n-heksan, kloroform, dan metanol kulit batang Artocarpus integer (Thunb.) Merr. Semua fraksi mengandung golongan senyawa terpenoid dan steroid. Aktivitas antibakteri ditentukan menggunakan metode difusi agar dengan media MHA (Muller Hinton Agar) terhadap Escherichia coli (gram negatif) dan Staphylococcus aureus (gram positif). Ciprofloxacin digunakan sebagai kontrol positif dan metanol sebagai kontrol negatif. Ketiga fraksi tersebut mampu menghambat pertumbuhan bakteri Escherichia coli dan Staphylococcus aureus. Fraksi kloroform menunjukkan aktivitas tertinggi setelah inkubasi 48 jam dengan zona hambat masing-masing yaitu 10.8 dan $10.4 \mathrm{~mm}$.
\end{abstract}

Kata kunci: Fraksi, Artocarpus integer (Thunb.) Merr, Fitokimia, Antibakteri

\begin{abstract}
This research aims to identify the compound group and determine the antibacterial activity of n-hexane, chloroform, and methanol fractions of Artocarpus integer (Thunb.) Merr stem bark. All fractions contain groups of terpenoid and steroid compounds. Antibacterial activity was determined using agar diffusion method with MHA (Muller Hinton Agar) media on Escherichia coli (gram negative) and Staphylococcus aureus (gram positive). Ciprofloxacin was used as a positive control and methanol as a negative control. The three fractions were able to inhibit the growth of Escherichia coli and Staphylococcus aureus. The chloroform fraction showed the highest activity after 48 hours incubation with inhibition zones of 10.8 and $10.4 \mathrm{~mm}$ respectively.
\end{abstract}

Keywords: Fractions, Artocarpus integer (Thunb.) Merr, Phytochemical, Antibacterial 


\section{INTRODUCTION}

Moraceae is a tropical plants that have the potential to produce secondary metabolites in relatively large quantities. The Moraceae family consists of 75 genus and 180 species (Hakim, 2010). The main genus of the family Moraceae is Artocarpus which consists of 50 species that spread in the South Asian region, Papua New Guinea, the South Pacific, and Indonesia (Hakim, 2010). Artocarpus plants are found in Indonesia with characteristic that is a tall tree with white sap in all parts of the plant, hardwood, fruit with flesh and many seeds. All parts of the Artocarpus plant have been used by many people for various purposes, one of which is traditional medicine. The plant $A$. camansi was believed to be able to treat blood sugar and skin drugs through decoction of leaves. The root of A. heterophyllus was used to treat fever, dysentery, and malaria, its leaves as a remedy for boils, fever, wounds, and skin diseases. A. integer fruit seeds have long been used by the people of Kampar (Riau Province) as a drug to treat diarrhea and for diabetes (Hilma et al., 2018).

Pharmacological studies in vitro and in vivo on the bioactivity of the genus Artocarpus have been widely performed, such as antimalarial activity (Boonlaksiri, et al., 2000), antioxidants (Zakaria et al., 2017), anticancer (Ganeson et al., 2017), antiproliverative (Hashim et al., 2012), antidiabetic (Nuntawong, et al., 2017), and antivirus (Hafid et al., 2017). Most of these pharmacological effects arise because of the content of flavonoids, terpenoids, stylbenoid, arylbenzofuran, neolignan and adducts Diels Alder (Hakim, 2010).

Antibacterials are chemical agents capable of inactivating bacteria. Inactivation of bacteria can be in the form of inhibition of bacterial growth (bacteriostatic) and can even kill bacteria (bactericidal) (Pelczar and Chan, 1988). The antibacterial potential in the genus Artocarpus can be seen from its minimum inhibitory concentration. Madhavi et al. (2013) reported that methanol extract of A. heterophyllus fruit sap had broad spectrum antibacterial activity that could inhibit the growth of Pseudomonas aeruginosa and Escherichia coli. In the same species, artocarpesin compounds were found which were able to inhibit the growth of Staphylococcus aureus (NavarroGarcia et al., 2012). The antibacterial activity of chloroform extract from $A$. integer stem wood provided a barrier zone of $13.80 \mathrm{~mm}$ against the bacterium Streptococcus pneumonia (Zakaria et al., 2017). The antimicrobial activity of ethanol extract of A. lakoocha bark on five test bacteria is bacteriostatic so that it can be developed as a source of antibiotic substances for drug development and in bacterial control (Nath and Boruah 2019).

The development of antibiotic drugs has special attention to researchers. This is due to the administration of antibiotics as the most appropriate solution for 
controlling pathogenic bacteria in infectious diseases. However, currently some antibiotics are no longer effective due to the emergence of resistant pathogenic bacteria. Data shows resistance to conventional antibiotics and it is estimated that in 2050 worldwide, 10 million people per year will die from infection by resistant microbes (Cordes et al., 2014). This condition encourages researchers to find effective new antibacterial agents capable of killing or fighting bacterial growth.

Although it has been known that the Artocarpus plant was ethnobotany used as a medicine, the chemical content and bioactivity of $A$. integer (Thunb.) Merr stem bark has not been reported. Therefore, this article will report on phytochemical tests and antibacterial activity with agar diffusion methods.

\section{MATERIAL AND METHOD \\ Instruments}

The instruments used in this study were distillation, rotary evaporator, buchner funnel, funnel, separating funnel, test tube, analytic balance, eppendorf micropipette, autoclave, aluminium foil, paper disk, petri dish, incubator, calipers, bunsen, lamp and glassware generally used in laboratories.

\section{Materials}

The materials used in this research were the stem bark powder of Artocarpus integer (Thunb.) Merr, organic solvents such as technical methanol, technical nhexane, chloroform p.a, LiebermannBuchard reagent, Dragendorff, Wagner, iron (III) chloride, pure culture of
Escherichia coli and Staphylococcus aureus, Nutrient Agar (NA) and Muller Hilton Agar (MHA) media, DMSO, ciprofloxacin, disc paper, aquadest, spiritus, $70 \%$ alcohol, aluminum foil, cling wrap and tissue roll.

\section{Methods}

\section{Sample collection}

Stem bark of Artocarpus integer (Thunb.) Merr was collected in September 2017 in Harapan Village, Mappedeceng District, North Luwu Regency, South Sulawesi. Plant identification was done at Herbarium Bogoriense, Biology Research and Development Center, LIPI Bogor (Zakaria, 2017)

\section{Extraction and phytochemical tests}

A total of $3 \mathrm{~kg}$ of bark powder macerated with methanol for $3 \times 24$ hours, then filtered to get the extract. The extract was concentrated using a rotary evaporator and then partitioned with several solvents to obtain the n-hexane, chloroform, and methanol fractions. All fractions were tested for phytochemical and antibacterial activity. Phytochemical tests included alkaloid test with Meyer and Wegner reagent, terpenoid test with LibermanBurchard reagent, steroid test with Liberman-Burchard and Salkowski reagents, flavonoid test using $\mathrm{Mg}$ and concentrated $\mathrm{HCl}$, and phenolic test with $\mathrm{FeCl}_{3}$ reagent.

\section{Antibacterial Activity Test}

Antibacterial activity tests were carried out on all fractions (n-hexane, 
chloroform and methanol) using agar diffusion methods, with variations in concentrations of $100,250,500 \mathrm{ppm}$ respectively. Ciprofloxacin was used as a positive control and methanol as a negative control. Incubation was carried out for 48 hours, and the clear zone was measured every 24 hours.

\section{RESULTS AND DISCUSSION}

\section{Phytochemical Test}

The result of the phytochemical test showed that the three fractions contained terpenoid and steroid compounds (Table 1).

Table 1. Phytochemical Test Results of n-Hexane, Chloroform and Methanol Fraction of A. integer (Thunb.) Merr Stem Bark

\begin{tabular}{cccccc}
\hline No. & Test & Reagents & \multicolumn{3}{c}{ Result } \\
\cline { 3 - 6 } & & & $n$-Hexane & Chloroform & Methanol \\
\hline 1 & Flavonoid & Mg + HCl Concentrated & - & ++ & ++ \\
\hline 2 & Terpenoid & Lieberman-Burchard & ++ & ++ & + \\
\hline 3 & Steroid & Salkowski & + & + & + \\
\hline 4 & Alkaloid & Wegner & + & - & - \\
& & Meyer & + & - & ++ \\
\hline 5 & Phenolic & $\mathrm{FeCl}_{3} 10 \%$ & - & ++ & +++ \\
\hline
\end{tabular}

The phenol and flavonoid compounds were founded in the chloroform and methanol fractions. The group of alkaloid compounds obtained in the n-hexane and methanol fractions. This is following the previous work reported by Hilma et al. (2018) against A. integer (Thunb.) Merr with fruit seed extract.

\section{Antimicrobial Test}

The results of the measurement of inhibition zones of n-hexane, chloroform, and methanol fractions against $E$. coli and $S$. aureus are shown in Table 2. 
Table 2. Antibacterial Activity of n-Hexane, Chloloform, and Methanol Fractons from A. integer (Thunb.) Merr Stem Bark Against E. coli and S. aureus

\begin{tabular}{|c|c|c|c|c|}
\hline \multirow{4}{*}{ Fractions } & \multicolumn{4}{|c|}{ Inhibition zone (mm) } \\
\hline & \multicolumn{2}{|c|}{ E. coli } & \multicolumn{2}{|c|}{ S. aureus } \\
\hline & 24 & 48 & 24 & 48 \\
\hline & hours & hours & hours & hours \\
\hline n-Hexane & 9.0 & 9.7 & 9.7 & 9.5 \\
\hline Chloroform & 9.4 & 10.8 & 9.8 & 10.4 \\
\hline Methanol & 8.9 & 10.1 & 9.4 & 9.7 \\
\hline Negative Control (Metanol) & 6.0 & 6.0 & 6.0 & 6.0 \\
\hline $\begin{array}{l}\text { Positive } \\
\text { (Ciprofloxacin) }\end{array}$ & 32.3 & 17.9 & 18.5 & 33.7 \\
\hline
\end{tabular}
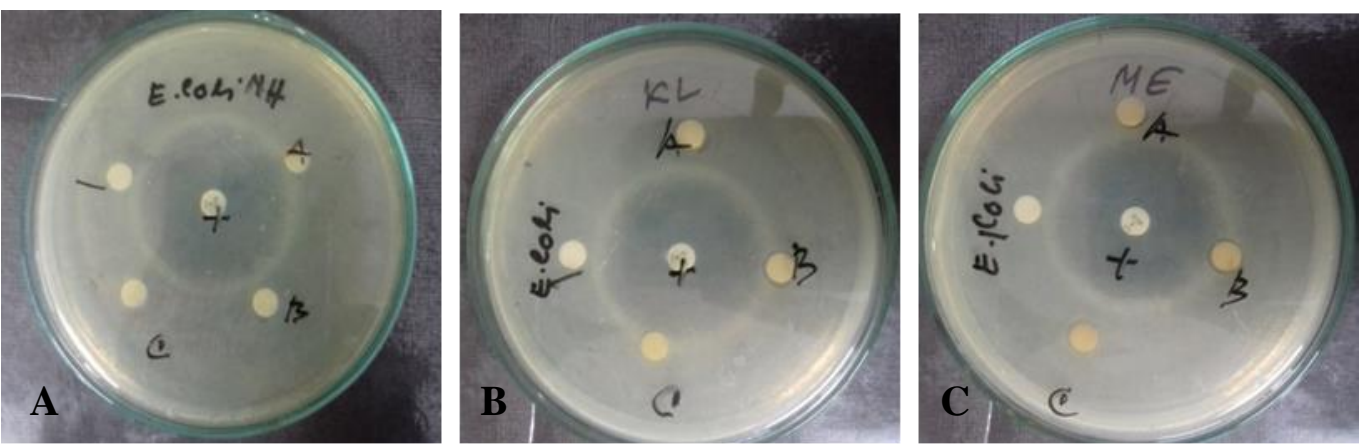

Figure 1. Inhibition zone for Escherichia coli, A. $n$-Hexane fraction; B. Chloroform fraction; C. Methanol fraction.
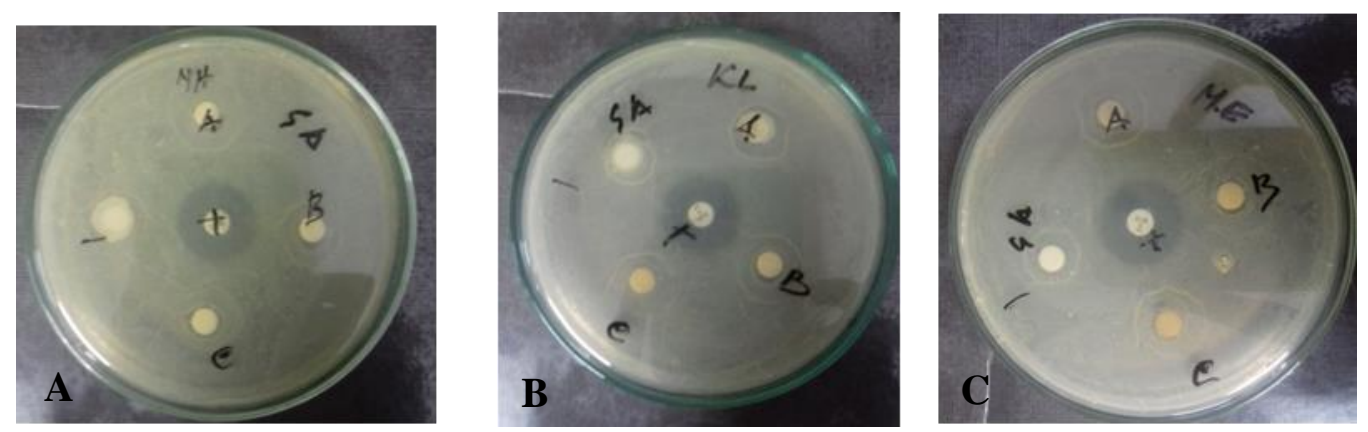

Figure 2. Inhibition zone for Staphylococcus aureus, A. $n$-Hexane fraction; B. Chloroform Fraction; C. Methanol fraction.

Generally n-hexane, chloroform, and methanol fractions can inhibit the growth of E. coli and S. aureus bacteria (Table 2).
The highest activity of each fraction was obtained at a concentration of $250 \mathrm{ppm}$. The fraction that gave the best inhibition 
zone to both bacteria was obtained in the chloroform fraction.

According to (David and Stout, 1971) inhibition zones of 5-10 mm was a moderate inhibition response. Ciprofloxacin provides the highest inhibition zone, when compared to the three stem bark fractions of $A$. integer (Thunb.) Merr. In gram negative bacteria, ciprofloxacin is bacteriostatic, whereas in gram positive is bactericidal (Pelczar and Chan, 1988).

\section{CONCLUSION}

The n-hexane, chloroform, and methanol fractions of A. integer (Thunb.) Merr stem bark contains compound groups of terpenoids and steroids. Chloroform fraction has the potential to be developed as an antibacterial because it has the highest inhibitory power $(10.80$ and $10.40 \mathrm{~mm})$ at 48 h incubation time on the growth of $E$. coli and S. aureus.

\section{REFERENCES}

Boonlaksiri, C., Oonanant, W., Kongsaeree, P., Kittakoop, P., Tanticharoen, M., and Thebtaranonth, Y., 2000, An Antimalarial Stilbene From Artocarpus integer. Pythochemistry, 54: 415-417.

Cordes, J., Wittersheim, M., Harder, J., and Glaser, R., 2014, The Skin's Own Antibiotics. Important Features of Antimicrobial Peptides for Clinical Practice, Hautarzt. 65 (1): 50-55.

David and Stout., 1971, Disc Plate Method of Microbiological Antibiotic Essay, Journal of Microbiology, 22 (4).
Ganeson, S., Adon, M.N., and Jamil, M.M.A., 2017, Artocarpus altilis Compound Based Study for AntiCancer Proliferation on the Hela Cell Electroporation Method. Journal of Fundamental and Applied Sciences, 9(4); 310-318.

Hafid, AF., Aoki-Utsubo, C., Permanasari, A.A., Adianti, M., Tumewu, L., Widyawaruyanti, A., Wahyuningsih, SPA., Wahyuni, TS., Lusida, MI, Soetjipto., and Hotta, H., 2017, Antiviral Activity of the Dichloromethane Extracts from Artocarpus heterophyllus Leaves against Hepatitis C Virus, Asian Pacific Journal of Tropical Biomedicine, 7 (7): 633-639.

Hakim, A., 2010, Diversity of Secondary Metabolites From Genus Artocarpus (Moraceae). Nusantara Bioscience, 2 (3); 146- 156.

Hashim, NM., Rahmani, M., Lian, E, GE, Sukari, MA., Yahayu, M., Oktima, W., Ali, AM., and Go, R., 2012, Antiproliferative Activity of Xanthones Isolated from Artocarpus obtusu, Page 9.

Hilma, R., Dewi, E.P., and Fadhli, H., 2018, Antimicrobial Activity and Antidiabetic Ethanol Extract of Cempedak Fruit Seeds in the Forest (Artocarpus integer (Thunb) Merr), Journal of Photon, 8 (2); 27-36.

Lotulung, P.D.N., Mozef, T,. Risdian, C. and Darmawan, A., 2014, In Vitro Antidiabetic Activities of Extract and Isolated Flavonoid Compounds from Artocarpus altilis (Parkinson) Fosberg. Indo, J. Chem, 14 (1); 7-11.

Madhavi, Y., Ragahava, R.K.V., and Ravi Kiran, C.H. 2013. Studies on Phytochemical Analysis and Antimicrobial Activity of Artocarpus 
heterophyllus Fruit Latex against Selected Pathogenic Microorganisms. International Journal of Scientific and Engineering Research, 4(10): 1456-1468.

Nath, P.C., and Boruah, S., 2019, Antimicrobial Activity of Ethanolic and Methanolic Extract of Artocarpus lakoocha Wall. Ex Roxb. (Moraceae) against Five Different Oral Bacterial Strains, International Journal of Current Microbiology and Aplieed Sciences, 8 (3): 1321-1325.

Navarro-Garcia, V.M., Salinas-Sanchez, D.O., Rodriguez-Flores, T.A., Abarca-Vargas, R., and AldanaLlanos, L., 2012, Antimicrobial Activity of Artocarpesin from Artocarpus heterophyllus Lam. Against Methiciliin-Resistant Staphylococcus aureus (MRSA). Journal of Medicinal Plants Research, 6 (34): 4879-4882.

Nuntawong, P., Kongkatitham, V., Likhitwitayawuid, K., Mekboonsonglarp, V., Sukrong, S., Tanasupawat, S., and Sritularak, B., 2017, New 2-arylbenzofuran From The Bark Root of Artocarpus gomezianus And Their $\alpha$-Glucosidase Inhibitory Activity, Natural Product Research, Page 1-6.

Pelczar, M.J., and Chan, E.C.S., 1988, Basics of Microbiology, UI Press, Jakarta.

Zakaria, Soekamto, N.,. Shah, Y.M., and Firdaus., 2017, Antibacterial Activity of The Arthocarpus integer (Thunb) Merr Fraction With The Agar Diffusion Method. E Journal of Plantation Products Industry (JIHP), 12 (2). 